\title{
MEKANISME CORPORATE GOVERNANCE TERHADAP KINERJA KEUANGAN PADA PERUSAHAAN PERBANKAN YANG TERDAFTAR DI BEI
}

\author{
Nurul Alfian \\ Universitas Madura, Pamekasan \\ Email: fian@unira.ac.id
}

KETERANGAN ARTIKEL

Riwayat Artikel

Diterima: 15 November 2019

Direvisi: 20 November 2019

Disetujui: 10 Desember 2019

Klasifikasi JEL

O16, M41

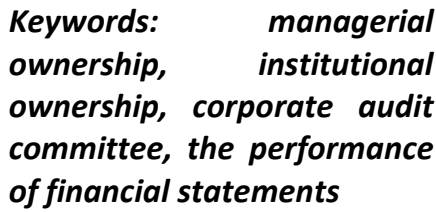

Kata kunci: kepemilikan manajerial, kepemilikan institusional, komite audit perusahaan dan kinerja laporan keuangan

\begin{abstract}
Implementationof good corporate governance can be considered as a way to improve the image of the bank declined, protect the interests of stakeholders and improve regulatory compliance to applicable law and ethics in the banking industry in improving the banking system is healthy. This research was conducted to examine the mechanism of corporate governance (managerial ownership, institutional ownership, and corporate audit committee) that affect the performance of financial statements. The research method use multiple linear regression analysis and the sampling technique use purposive sampling method. The results of this study present that there is a significant influence of managerial ownership, institutional ownership and corporate audit committee on financial performance.
\end{abstract}

\begin{abstract}
ABSTRAK
Implementasi good corporate governance dapat dinilai sebagai cara untuk memperbaiki citra dari perbankan yang menurun, melindungi kepentingan dari stakeholders, meningkatkan kepatuhan pada peraturan terhadap perundangundangan yang berlaku serta etika pada industri perbankan dalam meningkatkan sistem pada perbankan yang sehat. Penelitian ini dilakukan untuk menguji mekanisme corporate governance (kepemilikan manajerial, kepemilikan institusional, dan komite audit perusahaan) yang berpengaruh terhadap kinerja laporan keuangan. Metode penelitian menggunakan analisis regresi linier berganda dengan pemilihan sampel mengunakan metode purposive sampling. Hasil dari penelitian ini menyajikan bahwa ada pengaruh yang signifikan dari kepemilikan manajerial, kepemilikan institusional, dan komite audit perusahaan terhadap kinerja keuangan.
\end{abstract}

\section{PENDAHULUAN}

Kurangnya penerapan corporate governance dapat menjadi pemicu awal terjadinya berbagai kasus dalam keuangan. Berbagai kasus penipuan, penggelapan, pencurian, pembobolan serta korupsi yang dilakukan oleh beberapa oknum karyawan itu sendiri banyak yang terjadi khususnya di dunia perbankan. Contoh kasus yang melibatkan oknum karyawan adalah kasus yang terjadi di Citi Bank pada tahun 2011. Kasus tersebut melibatkan pegawai atau karyawan dari Citibank tersebut yang melakukan pembobolan dana nasabah sampai bernilai triliunan rupiah. Dampaknya berakibat kepada perbankan lainnya, disebabkan kasus ini 
Nurul Alfian: Mekanisme Corporate Governance ...

berhubungan dengan kepercayaan nasabah yang sedikit berkurang. Nasabah mulai mempertanyakan tentang keamanan dari dana mereka. Terjadinya berbagai kasus perbankan di Indonesia yang banyak terjadi dan yang melibatkan dari pihak oknum karyawan perbankan membuat banyak pihak untuk mulai berpikir bahwa penerapan tentang corporate governance dapat menjadi suatu kebutuhan dalam dunia bisnis sehingga dapat menjadi ukuran terhadap akuntabilitas pada sebuah perusahaan.

Implementasi terhadap good corporate governance dapat dinilai sebagai salah satu cara untuk memperbaiki citra dari perbankan yang sempat menurun, melindungi kepentingan dari stakeholders serta bertujuan untuk meningkatkan kepatuhan pada peraturan terhadap perundang-undangan yang berlaku serta etika pada industri perbankan dalam meningkatkan sistem pada perbankan yang sehat (Hutama, 2013). Corporate Governance lebih mengutamakan pada pola perilaku perusahaan yang dapat diukur dengan pertumbuhan, perlakuan pada pemegang saham, kinerja, struktur biaya dan stakeholders, sehingga dijadikan dasar dalam melakukan analisis terhadap corporate governance dalam suatu negara melalui transparansi dan akuntabilitas di dalam pengambilan keputusan yang dapat digunakan sebagai acuan dasar untuk pengukuran yang lebih tepat dan akurat tentang bagaimana kinerja perusahaan dan unutk mengetahui tentang hubungan antara kebijakan antara karyawan dan kinerja perusahaan. selain itu impelemntasi dari good corporate governance dalam dunia perbankan dapat diharapkan untuk dapat mempengauhi terhadap kinerja perbankan, dengan alasan implementasi dalam corporate governance dapat meningkatkan terhadap kinerja keuangan serta diharapkan dapat mengurangi berbagai risiko yang terjadi yang diakibatkan oleh tindakan dari pengelolaan yang lebih cenderung untuk menguntungkan diri sendiri maupun kelompok. perusahaan dalam menerapkan good corporate governance diharapkan akan lebih efisien dan dapat meningkatkan daya saing dalam setiap kegiatan.

Dalam keterbukaan terhadap fungsi, struktur, sistem serta pertanggung jawaban pada perusahaan sangat diperlukan sehingga dalam corporate governance dapat terlaksana secara efektif dan efisien yang dapat diungkapkan dengan kinerja pada laporan keuangan. akuntabilitas dan transparancy perusahaan merupakan karakteristik dalam laporan keuangan, yang dapat didefinisikan sebagai salah satu bentuk perluasan dalam hal laporan keuangan yang daat mengungkapkan pada entitas dengan berbagai cara yang dapat dipahami oleh penggguna pada laporan keuangan. Maka Entitas harus dapat mengelola secara terukur dan sesuai dengan kepentingan untuk perusahaan serta dapat mempertimbangkan terhadap kepentingan pemegang saham serta pemangku kepentingan lainnya, dengan harapan akan mencapai kinerja yang terus berkesinambungan hingga mencapaitujuan dari perusahaan.

Penelitian ini dilakukan untuk menguji mekanisme corporate governance (kepemilikan manajerial, kepemilikan institusional, dan komite audit perusahaan) yang berpengaruh terhadap kinerja laporan keuangan sekaligus meneliti faktor lain yang belum diteliti oleh peneliti terdahulu, yaitu komisaris independen serta menggunakan variabel penelitian terdahulu yaitu profitability dan leverage sebagai variabel kontrol.

Dalam hal pelaporan keuangan, peran dan tanggung jawab komite audit adalah memonitor dan mengawasi audit laporan keuangan dan memastikan agar standar dan kebijaksaan keuangan yang berlaku terpenuhi, memerikasa ulang laporan keuangan apakah sudah konsisten dengan informasi lain yang diketahui oleh anggota komite audit, serta menilai mutu pelayanan dan kewajaran biaya yang di ajukan auditor eksternal (KNKCG, 2002). Dalam penelitian ini tentang kualitas 
terhadap pelaporan keuangan yang dimaksud yaitu kinerja pada laporan keuangan.

\section{KAJIAN LITERATUR DAN PENGEMBANGAN HIPOTESIS \\ Corporate Governance}

Menurut Forum Corporate Governance In Indonesia (FCGI,2001) corporate governance adalah sebagai perangkat peraturan yang menetapkan hubungan antara pemegang saham, pengurus, pihak kreditur, pemerintah, karyawan, serta para pemegang kepentingan intern dan ekstern lainnya sehubungan dengan hak-hak dan kewajiban mereka. Corporate Governance dapat dikatakan sebagai sistem yang mengarahkan dan mengendalikan perusahaan.

Selanjutnya berdasarkan FCGI (2001) konsep corporate governance bertujuan untuk meningkatkan kinerja perusahaan melalui supervisi dan monitoring kinerja manajemen perusahaan dan untuk menjamin akuntabilitas perusahaan terhadap stakeholder dengan mendasarkan pada kerangka peraturan. Konsep corporate governance diajukan demi tercapainya pengelolaan laporan keuangan perusahaan yang lebih transparan bagi semua pengguna laporan keuangan. Corporate governance juga membantu menciptakan lingkungan kondusif demi terciptanya pertumbuhan yang efisien dan sustainable disektor korporat.

Sedangkan menurut Emirson (2007:135) menyatakan bahwa untuk memenuhi prinsip dari Good Corporate Governance suatu entitas diharapkan untuk dapat melakukan tata kelola perusahaan yang baik dan benar. maka unsurunsur dan perangkat GCG dapat terdiri dari komisaris, komite audit, pemegang saham, direksi manajer, sekretaris perusahaan dan karyawan serta auditor eksternal dan internal dan juga stakeholder lainnya'.

Beberapa penelitian menunjukkan adanya pengaruh antara Corporate Governance dan kinerja keuangan. Penelitian Sam'ani (2008) menunjukkan bahwa variabel kepemilikan institusional, aktivitas komisaris, ukuran dewan direksi, komisaris independen, komite audit dan rasio leverage berpengaruh terhadap kinerja keuangan. Penelitian Nahdiah (2009) yang menyimpulkan bahwa secara simultan jumlah dewan direksi, jumlah dewan komisaris dan jumlah komite audit mempunyai pengaruh yang signifikan terhadap kinerja keuangan. Selain itu, secara parsial jumlah dewan direksi mempunyai pengaruh signifikan terhadap kinerja keuangan, Jumlah dewan komisaris mempunyai pengaruh yang signifikan terhadap kinerja keuangan, Jumlah komite audit mempunyai pengaruh tidak signifikan terhadap kinerja keuangan.

\section{Kepemilikan Manajerial dan Kinerja Keuangan}

Kepemilikan manajerial adalah jumlah kepemilikan saham oleh pihak manajemen dari seluruh modal saham perusahaam yang dikelola Mukhtaruddin (2014). Kepemilikan manajerial di definisikan sebagai persentase saham yang dimiliki oleh pihak manajerial. Kepemilikan manajerial dianggap berhasil menjadi mekanisme untuk mengurangi masalah keagenan dengan kepentingankepentingan manajer dengan pemegang saham. Melalui kepentingan manajerial, kepentingan manajer dengan pemegang saham dapat disatukan jika proporsi kepemilikan saham yang dimiliki manajer dan direksi diperbesar, dimana proporsi saham yang dimiliki akan mengindikasikan menurunnya kecenderungan adanya tindakan manipulasi oleh manajemen (Jensen dan Meckling, 1976).

Para pemegang saham yang mempunyai kedudukan di manajemen perusahaan baik sebagai kreditur maupun sebagai dewan komisaris disebut sebagai kepemiikan manajerial. Adanya kepemilikan saham oleh pihak manajemen akan menimbulkan suatu pengawasan terhadap kebijakan-kebijakan yang diambil oleh manajemen perusahaan. 
Nurul Alfian: Mekanisme Corporate Governance ...

Kepemilikan manajerial akan mensejajarkan kepentingan manajemen dengan pemegang saham, sehingga manajer ikut merasakan secara langsung manfaat dari keputusan yang diambil dan ikut pula menanggung kerugian sebagai konsekuensi dari pengambilan keputusan yang salah.

Berdasarkan Komite Nasional Kebijakan Governance (KNKG) di tahun 2006, komisaris independen merupakan pihak yang tidak mempunyai hubungan bisnis dan kekeluargaan dengan pemegang saham pengendali, anggota direksi, dan dewan komisaris, serta dengan perusahaan itu sendiri. Dewan komisaris independen mampu menjalankan fungsi monitoring untuk mengawasi kebijakan serta kegiatan yang dilakukan oleh direksi sehingga dewan komisaris independen dapat memberikan kontribusi yang efektif dalam proses penyusunan laporan keuangan yang lebih berkualitas, laporan keuangan yang berkualitas menandakan nilai perusahaan tersebut juga baik (Muryanti dan Suardhika, 2014). Dewan komisaris dapat membentuk komite yang akan membantu melaksanakan tugas-tugasnya. Perusahaan yang sahamnya tercatat di BEI harus membentuk komite audit. Komite audit merupakan salah satu komponen GCG (Good Corporate Governance) yang berperan penting dalam sistem pelaporan keuangan dan berpengaruh dalam ketepatan waktu pelaporan keuangan (Pureno, 2012).

Dewan komisaris independen memainkan peran yang aktif dalam peninjauan kebijakan dan praktik laporan keuangan, sehingga dapat mempengaruhi ketepatan waktu pelaporan keuangan dalam suatu perusahaan (Hutama, 2013). Dewan komisaris juga dapat bertindak sebagai penengah dalam perselisihan yang terjadi antara para manajer internal dan mengawasi kebijakan manajemen serta memberikan nasehat kepada manajemen. Kehadiran dewan komisaris independen dalam persiapan pembuatan laporan keuangan dapat mengurangi waktu yang dibutuhkan perusahaan untuk mempublikasikan laporan keuangan kepada publik.

\section{Kepemilikan Institusional dan Kinerja Keuangan}

Agency problem akan secara langsung dapat berhubungan dengan struktur kepemilikan. Struktur kepemilikan yang terpecah tidak dapat memberikan insentif kepada para pemilik yang dapat memonitor terhadap pengelolaan pada manajemen. hal ini bisa disebabkan oleh para pemilik yang bisa menanggung sendiri semua biaya pengawasan (monitoring cost) yang dikeluarkan sehigga semua pihak khususnya pemilik akan menikmati semua manfaaat yang didapatkannya. investor pada perusahaan memiliki peranan dalam menyediakan penerapan yang dapat dipercaya oleh semua pihak baik internal maupun eksternal dalam penyajian informasi pada investor (Lastanti, 2004). Peranan ini dapat disebabkan investor di bidang investor pada institusi yang merupakan daya dalam pngendali yang lebih baik dibandingkan kepada investor individu.

Dengan menggunakan kepemilikan institusional, dalam keefektivan terhadap pengelolaan pada sumber daya perusahaan oleh manajemen yang bisa diketahui melalui reaksi pasar pada pengumuman laba. Persentase pada saham tertentu yang dimiliki oleh lembaga yang dapat mempengaruhi terhadap proses pada penyusunan laporan keuangan tidak menutup kemungkinan timbulnya aktualisasi yang sesuai dengan berbagai kepentingan dari pihak manajemen (Gideon, 2005:34). Kepemilikan institusional merupakan bagian dari kepemillikan saham perusahaan adalah kepemilikan saham perusahaan oleh institusi (badan). Tingkat pada kepemilikan institusional yang tinggi akan menimbulkan usaha dalam pengawasan yang lebih besar oleh para pihak investor institusional sehingga dapat menghalangi berbagai perilaku opportunistic terhadap manajer (Nahdiah, 2009). 


\section{Komite Audit dan Kinerja Keuangan}

Berdasarkan pada kerangka berpikir terhadap dasar hukum di Indonesia berbagai perusahaan-perusahaan publik tersebut dapat diwajibkan untuk membentuk komite audit. dewan komisaris oleh. Komite audit adalah suatu komite yang berpandangan tentang masalah akuntansi, laporan keuangan dan penjelasannya, sistem pengawasan internal serta auditor independen (FCGI, 2004). Menurut Keputusan Menteri nomor 117 Tahun 2004, tujuan dibentuknya komite audit adalah membantu komisaris atau dewan pengawas dalam memastikan efektifitas pelaksanaan tugas auditor eksternal dan auditor internal.

Seiring dengan karakteristik tersebut, otoritas komite audit juga terkait dengan batasan mereka sebagai alat bantu dewan komisaris. Mereka tidak mempunyai otoritas eksekusi apapun, tetapi hanya memberikan rekomendasi kepada dewan komisaris kecuali untuk hal spesifik yang telah memperoleh hak kuasa eksplisit dewan komisaris, misalnya: mengevaluasi dan menentukan kompensasi auditor eksternal dan memimpin suatu investigasi khusus (Aziz, 2009).

Dalam menjalankan perannya, komite audit harus memiliki hak terhadap akses tidak terbatas kepada direksi, auditor internal, auditor eksternal dan semua informasi yang ada di perusahaan. Tanpa otoritas atau hak atas akses tersebut, akan tidak mungkin komite audit dapat menjalankan perannya dengan efektif. Sejalan dengan arahan untuk menjalankan fungsi komite audit secara efektif, makaukuran sukses komite audit yang berhubungan dengan kegiatan organisasi adalah untuk memenuhi kebutuhan konsumen seperti pelayanan, kualitas dan biaya (Kusmadiyanto, 2011). Oleh karena itu, komite audit memiliki wewenang untuk melaksanakan dan mengesahkan penyelidikan terhadap masalah-masalah di dalam lingkungan tanggungjawabnya yang mempunyai tugas membantu dewan komisaris.
Oleh karena itu peran komite audit erat kaitannya dengan GCG dan dapat dijadikan tolak ukur sukses bagi suatu perusahaan. Komite audit merupakan pilar penting dalam penerapan GCG, karena komite audit juga berperan dalam mengevaluasi laporan keuangan.

\section{Hipotesis Penelitian}

$\mathrm{H} 1$ : Kepemilikan manajerial berpengaruh signifikan terhadap kinerja keuangan.

$\mathrm{H}$ 2: Kepemilikan institusional berpengaruh signifikan terhadap kinerja keuangan

H3: Komite audit berpengaruh signifikan terhadap kinerja keuangan.

H4: Kepemilikan manajerial, kepemilikan institusional, dan komiteaudit berpengaruh signifikan terhadap kinerja keuangan.

\section{METODE PENELITIAN}

Pada penelitian ini jenis data yang digunakan adalah jenis data kuantitatif. Pemilihan sampel mengunakan metode purposive sampling. Analisis data dalam penelitian ini menggunakan analisis regresi linier berganda untuk pengujian hipotesis, analisis regresi ini selain mengukur kekuatan hubungan antara dua variabel atau lebih, juga menentukan arah hubungan antara variabel dependen dengan variabel independen.

\section{Uji Regresi Linier Berganda}

Model persamaan regresi untuk menguji apakah ada pengaruh signifikan antara variabel independen terhadap variabel dependen dalam penelitian ini adalah sebagai berikut.

$$
Y=a+b_{1} X_{1}+b_{2} x_{2}+b_{3} x_{3}+e
$$

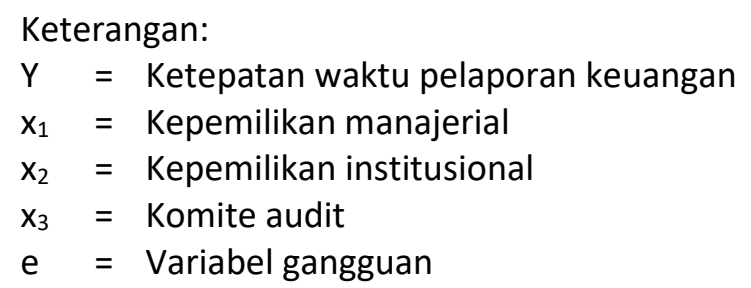




\section{HASIL PENELITIAN DAN PEMBAHASAN Uji Hipotesis}

Pengujian hipotesis dilakukan dengan uji statistik $t$ dan uji $f$ yakni dengan menguji pengaruh variabel kepemilikan manajerial, kepemilikan manajerial, komite audit terhadap kinerja keuangan secara parsial dan simultan.

\section{Uji t (parsial)}

Hasil uji $t$ dalam penelitian ini dapat dilihat pada tabel sebagai berikut.

Tabel 1. Hasil Uji t

\begin{tabular}{|c|c|c|c|c|c|c|}
\hline \multicolumn{7}{|c|}{ Coefficients $^{\mathrm{a}}$} \\
\hline \multirow{2}{*}{\multicolumn{2}{|c|}{ Model }} & \multicolumn{2}{|c|}{$\begin{array}{l}\text { Unstandardized } \\
\text { Coefficients }\end{array}$} & \multirow{2}{*}{$\begin{array}{l}\text { Standardize } \\
d \\
\text { Coefficients } \\
\text { Beta }\end{array}$} & \multirow[t]{2}{*}{$\mathrm{t}$} & \multirow[t]{2}{*}{ Sig. } \\
\hline & & B & $\begin{array}{l}\text { Std. } \\
\text { Error }\end{array}$ & & & \\
\hline \multirow[t]{4}{*}{1} & (Constant) & 5,789 & 9,540 & & 16,078 &, 000 \\
\hline & $\begin{array}{l}\text { Kepemilikan } \\
\text { manajerial } \\
\text { (X1) }\end{array}$ & ,349 & 4,830 & ,032 & 198 & , 027 \\
\hline & $\begin{array}{l}\text { Kepemilikan } \\
\text { institusional } \\
(\mathrm{X} 2)\end{array}$ & ,012 & , 073 & ,054 & ,374 & , 049 \\
\hline & $\begin{array}{l}\text { Komite audit } \\
\text { (X3) }\end{array}$ & 605 & 3,766 & 103 & ,294 & 031 \\
\hline
\end{tabular}

Sumber: Hasil Olah Data SPSS, 2019

Berdasarkan hasil perhitungan sig. $t$ $0,027<0,05$ maka Ha diterima dan Ho ditolak. Artinya, kepemilikan manajerial secara parsial berpengaruh signifikan terhadap kinerja keuangan. Perhitungan sig t 0,049 $<0,05$ maka $\mathrm{Ha}$ diterima dan HO ditolak. Artinya, kepemilikan institusional berpengaruh signifikan terhadap kinerja keuangan. Perhitungan sig t 0,031<0,05 maka $\mathrm{Ha}$ diterima dan Ho ditolak. Artinya, komite audit berpengaruh signifikan terhadap ketepatan waktu pelaporan keuangan.

\section{Uji F (Uji simultan)}

Berdasarkan tabel hasil perhitungan statistik diperoleh nilai F-hitung disajikan pada tabel 2 berikut.

Tabel 2. Hasil Uji $f$

\begin{tabular}{llrrrrr}
\hline \multicolumn{7}{c}{ ANOVA $^{\mathbf{b}}$} \\
\hline \multirow{2}{*}{1} & Model & $\begin{array}{c}\text { Sum of } \\
\text { Squares }\end{array}$ & Df & $\begin{array}{c}\text { Mean } \\
\text { Square }\end{array}$ & F & Sig. \\
\hline \multirow{2}{*}{1} & Regression & 13,675 & 2 & 11,290 & 4,519 &, $031^{\text {a }}$ \\
\cline { 2 - 6 } & Residual & 156,780 & 32 & 42,351 & & \\
\cline { 2 - 6 } & Total & 132,460 & 33 & & &
\end{tabular}

a. Predictors: (Constant), komite audit, kepemilikan manajerial, kepemilikan institusional

b. Dependent Variable: ketepatan waktu 
Dari hasil analisis diperoleh profitabilitas signifikan 0,031 , sedangkan dengan $0,031<0,05$, maka dalam penelitian ini uji $\mathrm{F}$ mendapatkan hasil bahwa variabel kepemilikan manajerial(X1), kepemilikan institusional (X2), komite audit (X3) secara bersama-sama mempunyai pengaruh terhadap kinerja keuangan (Y).

\section{Uji Koefisien Determinasi $\left(\boldsymbol{R}^{2}\right)$}

Hasil uji determinasi (R2) dapat dilihat dari nilai koefisien determinasi pada tabel 4.11 berikut.

Tabel 3. Uji Koefisien Determinasi $\left(R^{2}\right)$

\begin{tabular}{|c|c|c|c|c|}
\hline \multicolumn{5}{|c|}{ Model Summary } \\
\hline Model & $\mathrm{R}$ & R Square & $\begin{array}{c}\text { Adjusted R } \\
\text { Square }\end{array}$ & $\begin{array}{l}\text { Std. Error of } \\
\text { the Estimate }\end{array}$ \\
\hline 1 & $.181^{\mathrm{a}}$ & .303 & .075 & .2586 \\
\hline \multicolumn{5}{|c|}{ a. Predictors: (Constant), X1,X2,X3 } \\
\hline b. Depe & lent & iable: Y & & \\
\hline
\end{tabular}

Berdasarkan Tabel 3 di atas diperoleh angka $R^{2}$ (R Square) sebesar 0,303 atau $(30,3 \%)$. Hal ini menunjukkan bahwa persentase variabel kepemilikan manjerial, kepemilikan institusional dan komite audit terhadap kinerja keuangan sebesar 30,3\%. Dengan kata lain variabel kinerja keuangan dapat dijelaskan atau dipengaruhi oleh variabel kepemilikan manjerial, kepemilikan institusional dan komite audit sebesar 30,3\%, sedangkan sisanya sebesar $69,7 \%$ dijelaskan atau dipengaruhi oleh variabel lain yang tidak diteliti.

\section{Pembahasan \\ Pengaruh Kepemilikan Manjerial terhadap Kinerja Keuangan}

Penelitian ini menunjukkan bahwa kepemilikan majerial berpengaruh terhadap kinerja keuangan. Hasil penelitian menunjukkan bahwa di Indonesia banyak pihak manajemen yang memiliki saham perusahaan dengan jumlah yang cukup signifikan. Hasil yang signifikan menunjukkan bahwa pasar menggunakan informasi mengenai kepemilikan manajemen dalam melakukan penilaian investasi. Hal ini diduga karena kondisi di Indonesia, dimana proporsi kepemilikan manajerial dalam perusahaan masih sangat rendah, sehingga penerapan kepemilikan manajerial untuk membantu penyatuan kepentingan antara manajer dan pemilik agar dapat memotivasi manajer dalam melakukan tindakan guna meningkatkan kinerja perusahaan belum dapat berjalan efektif.

Penelitian ini sejalan dengan penelitian yang dilakukan Pureno (2012) yang meneliti tentang pengaruh mekanisme good corporate governance terhadap kinerja perusahaan perbankan yang terdaftar dibursa efek indonesia tahun 2009-2011, dengan inidkator diantaranya adalah kepemilikan manjerial. Maka menyatakan bahwa kepemilikan manjerial memiliki pengaruh terhadap kinerja keuangan. Selain itu Tarigan (2015) juga meneliti pengaruh kepemilikan institusional terhadap kinerja keuangan melalui struktur modal sebagai variabel intervening pada perusahaan manufaktur yang terdaftar dalam bursa efek indonesia (BEI). Bahwa hasil penelitian kepemilikan manjerial berpengaruh terhadap kinerja keuangan.

\section{Pengaruh Kepemilikan Institusional terhadap Kinerja Keuangan}

Hasil penelitian menunjukkan bahwa semakin tingginya kepemilikan institusional maka dapat dikatakan bahwa akan semakin baik pula pengawasan terhadap 
perusahaan,sehingga perusahaan akan semakin baik terhadap kinerjanya. Dapat dikatakan bahwa kepemilikan institusional bertindak sebagai pihak yang memonitor dan sebagai pengontrol dari perusahaan padaumumnya dan manajer sebagai pengelola dalam perusahaan pada khususnya (Jumingan, 2006).

Dalam penelitian ini sejalan dengan penelitian yang telah dilakukan oleh Sam'ani (2008) yang berjudul Pengaruh Good Corporate Governance dan Leverage Terhadap Kinerja Keuangan Pada Perbankan Yang Terdaftar Di Bursa Efek Indonesia (BEI) pada Tahun 2004-2007, dengan hasil penelitian menunjukkan bahwa dalam variabel kepemilikan institusional hasilnya berpengaruh terhadap kinerja keuangan. Penelitian yang dilakukan oleh Ndaruningpuri (2006) Menunjukkan hasil institusional ownership sebagai indikator mekanisme corporate governance, yang secara signifikan berpengaruh positif terhadap kinerja perusahaan.

\section{Pengaruh Komite Audit terhadap Kinerja Keuangan}

Hasil penelitian ini menunjukkan bahwa komite audit berpengaruh terhadap kinerja keuangan. Hasil dari penelitian menunjukkan bahwa auditor internal dalam komite audit ini yang memiliki peran terpenting dalammengendalikan perusahaan, agar perusahaan berjalan baik dan efektif biladibandingkan dengan para manajer. Jumlah pada komite audit yang tidak dapat mencukupiperusahaan juga berpengaruh terhadap bagaimana kinerja perusahaan tersebut karenajumlah dari komite audit juga harus disesuaikan dengan kompleksitas kekgiatan perusahaan. Jumlah dari komite audit yang dimiliki perusahaan minimal terdiri dari tigaorang, yang masing masing satu orang dari komisaris independen dan dua orang dari luarperusahaan.

Penelitian ini juga sejalan dengan penellitian yang pernah dilakukan oleh
Sam'ani (2008) menunjukkan bahwa variabel komite audit berpengaruh terhadap kinerja keuangan. Selain itu penelitiannya juga sama dengan penelitin yang dilakukan oleh Pureno (2012) yang menyatakan bahwa kepemilikan manjerial memiliki pengaruh terhadap kinerja keuangan. Selain itu, Tarigan (2015) dalam penelitiannya juga meneliti dengan judul pengaruh kepemilikan institusional terhadap kinerja keuangan melalui struktur modal sebagai variabel intervening pada perusahaan manufaktur yang terdaftar dalam bursa efek indonesia (BEI). Bahwa hasil penelitian yang didapat adalah komite audit berpengaruh terhadap kinerja keuangan.

\section{Pengaruh Kepemilikan Manjerial, Kepemilikan Intitusional, dan Komite Audit terhadap Kinerja Keuangan}

Hasil dari penelitian ini menunjukan bahwa dalam kepemilikan manjerial, kepemilikan intitusional, dan komite audit ketiga variabel tersebutyang lebih kuat dan lebih mendominansi dalam mengurangi perilaku oportunistik manajemensehingga dapat meningkatkan besarnya kualitas dan keandalan dalam hal pelaporan keuangan sertakinerja keuangan. Mekanisme pada good corporate governance yang solid dan sesuai akan mengarahkan dan juga mengendalikan perusahaan dengan tujuan, agar dapat mencapai keseimbanganantara kekuatan kewenangan yang diperlukan oleh perusahaan untuk menjamin kelangsungan eksistensinya dan pertanggungjawaban kepada stakeholder. Sehingga dengan mekanisme good corporate governance orangorangyang berkepentingan dalam perusahaan tersebut akan tercapai tujuandan peningkatan kinerja keuangan.

\section{PENUTUP}

Hasil penelitian ini menunjukkan bahwa variabel kepemilikan manajerial, kepemilikan institusional, dan komite audit berpengaruh secara signifikan terhadap ketiga variabel independen terhadap kinerja keuangan 
pelaporan keuangan baik diuji dengan uji t, uji f dan uji $R^{2}$.

Dengan demikian maka dengan adanya kepemilikan manajerial, kepemilikan institusional, dan adanya komite audit perusahaan cenderung akan memiliki kinerja keuangan yang baik. Hal tersebut menunjukkan adanya pengendalian yang komprehensif dari ketiiga factor tersebut. Dapat disimpulkan bahwa perusahaan yang telah mengimplementasikan corporate governance akan cenderung memiliki kinerja keuangan yang baik.

Saran untuk penelitian selanjutnya adalah dapat menambahkan variable dimensi CG dan melakkukan pengujian pada sector lainnya. Selain itu dengan rentang waktu penelitian yang lebih panjang. Hal tersebut untuk meningkatkan generalisasi hasil penelitian.

\section{REFERENSI}

Azis, A. (2009). Corporate Governance. Yogyakarta: AR-RUZZ Media.

Gideon, Boediono SB. (2005). Kualitas Laba: Studi Pengaruh Mekanisme Corporate Governance dan Dampak Manajemen Laba dengan Menggunakan Analisis Jalur. Simposium Nasional Akuntansi X.

Djarwanto dan Pangestu. (2003). Pengaruh Good Corporate Governance dan Pengungkapan Corporate Social Responsibility Terhadap Nilai perusahaan. Skripsi. Universitas Negeri Yogyakarta.

Emirson, J. (2007). Teori Akuntansi. Jakarta: PT Raja Grafindo Persada.

FCGI. (2004). Corporate Governance Self Assessment Corporate Governance Self Assessment Checklist. Penilaian Mandiri (Self Assessment) Praktik Corporate Governance Perusahaan.

Ghozali. I. (2016). Aplikasi Analisis Multivariete dengan program IBM SPSS 23 (Edisi 8). Cetakan ke VIII. Semarang: Badan Penerbit Universitas Diponegoro.
IAI. 2004. Pernyataan Standar Akuntansi Keuangan. Jakarta: Salemba Empat.

__. 2007. Pernyataan standar akuntansi keuangan. Jakarta: Salemba Empat.

Jensen and Meckling. (1976). Theory of Firm: Managerial Behaviior Agency Cost and Ownership Structure. Journal of Financial Economics.

Jumingan. (2006). Analisis Struktur Kepemilikan Nilai Perusahaan. Investasi. Dan Ukuran Dewan Direksi. Simposium Nasional Akuntansi VI.

Keputusan Menteri nomor 117 Tahun 2004 Tentang Badan Usaha Milik Negara.

KNKG. (2006). Pedoman umum Good Corporate Governance Indonesia.

Kusmadiyanto. (2011). Pengaruh Mekanisme Good Corporate Governance terhadap Kinerja Perbankan Nasional. Skripsi. Universitas Diponegoro Semarang.

Lastanti, Sri H. (2004). Pengaruh penerapan Corporate Governance terhadap likuiditas perbankan nasional. Skripsi. Fakultas Ekonomi Universitas Diponegoro Semarang.

Mukhtaruddin. (2014). Good Corporate Governance Mechanism, Corporate Social Responsibility Study On Lusted Company In Indonesia Stock Exchange. Internal Journal of Finance And Accounting Studies, Vol.2, No. 1.

Muryanti dan Suardhika. (2014). Pengaruh Corporate Governance Pada Nilai Perusahaan. Skripsi. Universitas Udayana.

Nahdiah, N. (2009). Pengaruh Mekanisme Good Corporate Governance Terhadap Kinerja Keuangan Pada Perusahaan Barang Konsumsi Yang Terdaftar Di BEI. Skripsi. Universitas Pembangunan Nasional Veteran Yogyakarta.

Ndaruningpuri, W. (2006). Pengaruh indikator Mekanisme Corporate Governance Terhadap Kinerja Perusahaan Publik Di Indonesia. Jurnal Fokus Ekonomi. Vol 1 No 2. 
Peraturan Bapepam Nomor X.K.2, Lampiran Keputusan Ketua Bapepam Nomor: KEP36/PM/2003 tentang Kewajiban Penyampaian Laporan Keuangan Berkala

Pureno, D. (2012). Pengaruh Mekanisme Good Corporate Governance terhadap Kinerja Perusahaan Perbankan yang Terdaftar di Bursa Efek Indonesia Tahun 20092011. Skripsi. Universitas Negeri Yogjakarta.

Hutama, Redo H. (2013). Good Corporate Governance sebagai Salah Satu Faktor Penilaian Tingkat Kesehatan Bank
Umum. Privat Law Edisi 03 Nov. 2012Maret 2013.

Sam'ani. (2008). Pengaruh Good Corporate Governance dan Leverage terhadap Kinerja Keuangan Pada Perbankan yang Terdaftar Dibursa Efek Indonesia pada Tahun 2004-2007. Skripsi. Universitas Diponegoro Semarang

Tarigan. (2015). Pengaruh Kepemilikan Institusional terhadap Kinerja Keuangan Melalui Struktur Modal Sebagai Variabel Intervening pada Perusahaan Manufaktur Yang terdaftar Dalam Bursa Efek Indonesia (BEI). Skripsi. Universitas Gunadarma. 